\title{
Going Green- The Road ahead for Green Challenges in India
}

\author{
Kasinathan Karmugilan, B. Rajeswari
}

\begin{abstract}
The paper aims to understand how people respond to the recent changes that are made due to environmental depletion. Green products are an outcome of the demand made by consumers and various government regulations over the manufacturers to maintain a sustainable environment. The knowledge of a consumer is highly important in identifying an actual green product over a presumed one.

Purpose: To measure their level of perception and knowledge about a green product among various age groups and occupational categories.

Methodology: Structural equation modeling (SEM) is used to study the relationship of green product perception and green product knowledge over green purchase intention. Garrett ranking was used to measure the reasons of purchase.

Findings: Green product perception has more impact over green purchase intention than green product knowledge. Necessity and cost of the product were the main reasons for purchasing a product.

Implications: The green product perception was more influential in green purchase intention. Hence these factors may be taken for consideration in improving the product quality meeting the perception of consumers about the product. Keeping a regular check over the product's quality may also improve the sales of the product.
\end{abstract}

Keywords: Green products, consumers, knowledge and perception.

\section{INTRODUCTION}

Environmental concern has become a major factor in the recent times due to the impacts faced by the depletion of natural resources. Products that are environment friendly and as well the users began to gain popularity. A green product is the one which causes less or no harm to its environment throughout its production to disposition stage. A product that causes minimal impact on the environment and more sustainable is called as green product. Green marketing is known as the promotion and marketing of green products. Environmental concern may be defined as the attitude and belief of an individual which influences them towards their environmental well-being [1] [2]. Though environmental awareness was more prevalent in the European and American continents, the Asian sub continents too gained popularity ad awareness about environmental safety and retaining over the years. The UNESCO conference held at Belgrade was the first step to create awareness among the people about

Revised Manuscript Received on July 22, 2019.

Kasinathan Karmugilan*, Department of Management Studies, Pondicherry University, Puducherry, India. Email:

Dr.B.Rajeswari, Department of Management Studies, Pondicherry University, Puducherry, India.. Email: raajeebster@gmail.com karmugilan88@gmail.com

environmental safety, environmental conscious and participating for the collective growth [3]. The role of advertisements played a key part in the sales of a product, majority of the sellers acclaimed their products as environmentally friendly one to increase sales volumes. [4]. Green marketing is a subset of societal marketing [5]. People using eco-friendly products were called green consumers, products with eco-friendly labels were termed as green or ecofriendly products and marketing of these products was termed as green marketing [6]. The last decade of the nineteenth century had a shift of marketing perspective of green products towards education aspects based on consumer's perspectives like purchase intention, attitude, behaviour and interest [7]. Green marketing made the channels of marketing structured and regulated. The growth of green marketing was also steadily increasing. A product that is manufactured by damaging the environment, involving any animals, utilising more non-renewable resources, unethical testing over animals or humans are not supported by a green consumer [8].The activities that are designed to satisfy human needs with minimal or no impact on natural environment [9]. Lean manufacturing, high efficiency and more profitability drew the attention of manufacturers towards green manufacturing process [10]. The actual the growth of green market was at a positive stream, while there was a controversy about the growth of green market to be positive or negative. [11] [12]. There was a huge difference in consumer's interest towards green products and actually purchasing those [13]. Globalisation was a main factor that propelled the expansion of green market [14]. The sustainability of the manufacturers can be increased by segmenting the consumers based on their requirements and manufacturing accordingly [15]. The guarantee for quality in the manufacture of eco-friendly products was put forth by consumers, stakeholders and social organisations [16]. Pricing was not a major concern among elite consumers. Their social status factor was more influential than the environmental concern [17]. The manufacturing and marketing of green products increased as the demand kept on increasing gradually [18].Consumers with more interest in purchase of green products were having prior knowledge and were familiar with eco labeling [19]. Education plays a major role in inducing social concern and environmental concern in an individual [20]. Apart from commercial values a product must have some environmental benefits to increase its sales [21]. 


\section{OBJECTIVES OF THE STUDY}

1. To study the association of green product knowledge, green product perception with green purchase intention among consumers of green products.

2. To know the reasons that prioritizes the motives of purchase intention among green product consumers.

\section{SCOPE FOR THE STUDY VARIABLES}

The study emphasizes on purchase intention that has number of driving factors. Green product knowledge (GPK), Green product perception (GPP) and their influence on Green purchase intention (GPI) were the major variables for this study. Attitude has been studied as an important factor in most of the earlier studies but knowledge which is a key component in determining attitude is not concentrated more. Perception about green products was also concentrated less in most of the studies related to purchase intention creating plot for the study. The priority of the consumers in selecting and purchasing a product were also considered in the study.

\section{Methodology}

Consumers who were involved in purchasing green products were taken for the study. Purposive sampling method was carried out for sample selection. A structured questionnaire using five point likert scale was constructed adopting from existing scales. Green product knowledge consists of five statements, Green product perception consists of eight statements and green purchase intention comprises of seven statements. The reasons of purchase consisted of seven statements. A total of 800 questionnaires were distributed from which 421 were obtained from consumers who were using green products at a strike rate of $52.6 \%$. After excluding unengaged responses and incomplete questionnaires a total of 393 responses were taken for carrying further analysis. Confirmatory factor analysis was calculated to measure the constructs. Structural equation modeling was carried out to study the relationship among the variables and Garrett ranking was used to measure the ranking of priority in purchase reasons.

Sampling method: Purposive sampling, non-probability technique

Questionnaire: Structured Questionnaire with five point likert scale questions

Software: Microsoft Excel, IBM AMOS

Statistical tools: Confirmatory factor analysis (CFA),

Structural equation modelling (SEM) and Garrett ranking.

\section{ANALYSIS AND FINDINGS}

From the table 1 it can be inferred that, factor loadings of all the factors are above 0.5 . The values display the overall reliability of the constructs measured. The corresponding Cronbach's alpha, average variance explained and composite reliability values must be greater than $0.6,0.5$ and 0.6 respectively. The results from the above mentioned table show that all the constructs have the minimum threshold values. The above values can be confined as optimum for carrying out further analysis and building the model. The table 2 shows value of AVE and squared correlation. The values shown in bold are square root of AVE scores and must be greater than the values of squared correlation to determine the absence of relationship. The values of table 2 establish discriminant validity since there is no relationship among the constructs.

\section{Figure 1}

Green purchase intention- Confirmatory factor analysis

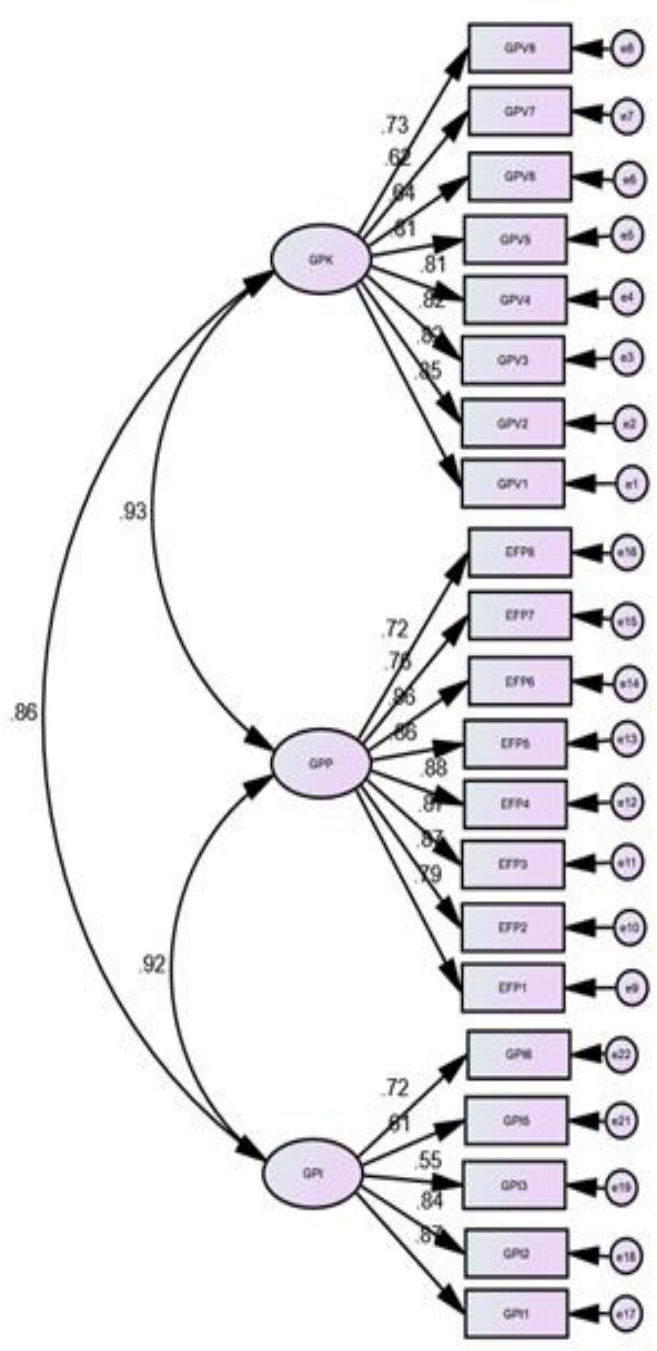

Table 1

Discriminant validity for the constructs

\begin{tabular}{|l|l|l|l|}
\hline & GPK & GPP & GPI \\
\hline GPK & $\mathbf{0 . 7 6 8}$ & & \\
\hline GPP & 0.782 & $\mathbf{0 . 8 2 8}$ & \\
\hline GPI & 0.658 & 0.919 & $\mathbf{0 . 7 2 9}$ \\
\hline
\end{tabular}


Table 2

Reliability and validity for the constructs

\begin{tabular}{|c|c|c|c|c|c|}
\hline & Factor & $\begin{array}{c}\text { Factor } \\
\text { score }\end{array}$ & $\begin{array}{c}\text { Cron } \\
\text { bach's } \\
\text { alpha }\end{array}$ & AVE & CR \\
\hline \multirow{8}{*}{ GPK } & GPV1 & 0.852 & \multirow{8}{*}{0.92} & \multirow{8}{*}{0.591} & \multirow{8}{*}{0.919} \\
\hline & GPV2 & 0.823 & & & \\
\hline & GPV3 & 0.825 & & & \\
\hline & GPV4 & 0.809 & & & \\
\hline & GPV5 & 0.807 & & & \\
\hline & GPV6 & 0.641 & & & \\
\hline & GPV7 & 0.621 & & & \\
\hline & GPV8 & 0.729 & & & \\
\hline \multirow{8}{*}{ GPP } & EFP1 & 0.79 & \multirow{8}{*}{0.945} & \multirow{8}{*}{0.685} & \multirow{8}{*}{0.945} \\
\hline & EFP2 & 0.873 & & & \\
\hline & EFP3 & 0.866 & & & \\
\hline & EFP4 & 0.884 & & & \\
\hline & EFP5 & 0.861 & & & \\
\hline & EFP6 & 0.859 & & & \\
\hline & EFP7 & 0.756 & & & \\
\hline & EFP8 & 0.716 & & & \\
\hline \multirow{5}{*}{ GPI } & GPI1 & 0.872 & \multirow{5}{*}{0.861} & \multirow{5}{*}{0.531} & \multirow{5}{*}{0.846} \\
\hline & GPI2 & 0.84 & & & \\
\hline & GPI3 & 0.547 & & & \\
\hline & GPI5 & 0.612 & & & \\
\hline & GPI6 & 0.721 & & & \\
\hline
\end{tabular}

Figure 2

Structural equation model for green purchase intention

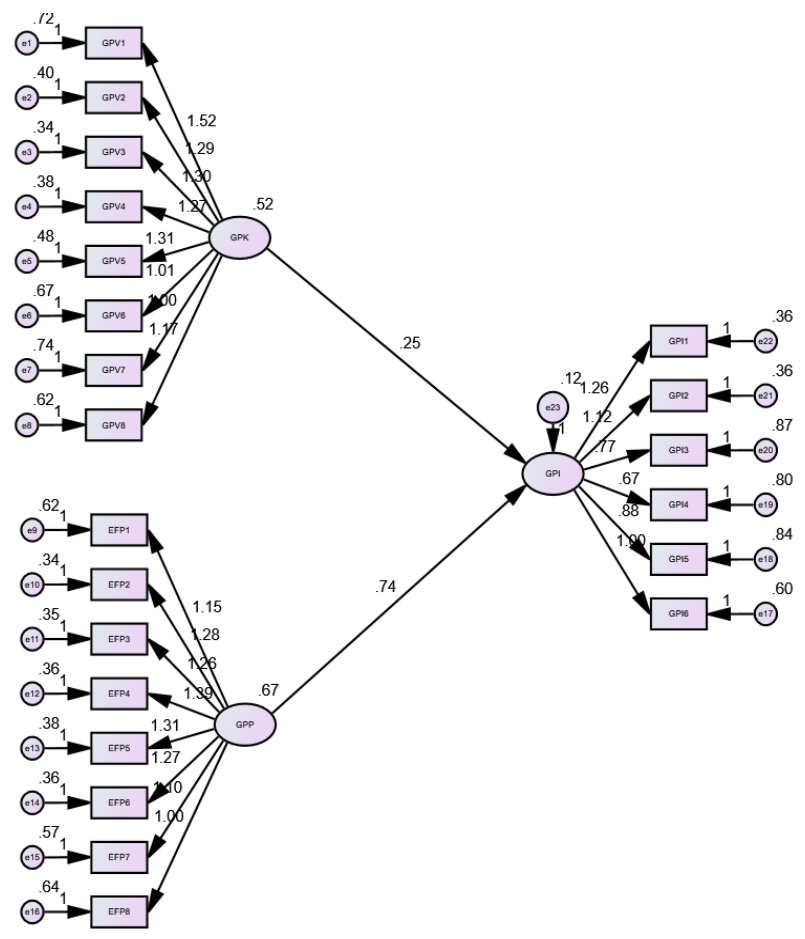

Table 3

Model fit summary

\begin{tabular}{|l|l|l|l|l|l|}
\hline $\begin{array}{l}\text { CMIN } \\
\text { /DF }\end{array}$ & $\begin{array}{l}\text { P } \\
\text { Value }\end{array}$ & GFI & AGFI & CFI & RMSEA \\
\hline 4.695 & 0.00 & 0.941 & 0.922 & 0.954 & 0.069 \\
\hline$[1-5]$ & $>0.05$ & $>0.9$ & $>0.9$ & $>0.9$ & $<0.08$ \\
\hline
\end{tabular}

From the above table 3, it can be observed that normed chi square value is 4.695. 0.941 is the GFI value, 0.922 is AGFI value, 0.954 is CFI value and 0.069 is the RMSEA value. It is observed that all the values are within the observed range. Since all the values are within the threshold limit it can be considered that the model fit measures are tolerable and proceed for further analysis.

Table 4

Summary of estimates

\begin{tabular}{|l|l|l|l|l|l|}
\hline & $\begin{array}{l}\text { Estimat } \\
\mathrm{e}\end{array}$ & S.E & C.R & $\begin{array}{l}\text { P } \\
\text { Value }\end{array}$ & Result \\
\hline $\begin{array}{l}\text { GPI } \\
\text { GPK }\end{array}$ & 0.225 & 0.039 & 5.767 & 0.000 & $\begin{array}{l}\text { In- } \\
\text { significant }\end{array}$ \\
\hline $\begin{array}{l}\text { GPI } \leftarrow \\
\text { GPP }\end{array}$ & 0.763 & 0.063 & 12.10 & 0.000 & Significant \\
\hline
\end{tabular}

The summary of estimates table. 4 displays the role of green product knowledge over the influence of purchase intention of green products. Consumers may be having knowledge about the product and its attributes, but not necessarily have to purchase the product. Many other factors may play an influential part in motivating purchase intention among the consumers. Green product perception shows a positive influence towards the consumers green purchase intention. The perception about the product like its quality, performance, materials used etc. plays a vital role in influencing green purchase intention.

\section{Garrett ranking}

The below table 5 represents Garrett score values for factors that are important in making a purchase decision. According to the scores obtained the factors were ranked. Necessity was the top most priority in purchasing a product. Cost of the product and brand reputation were in second and third positions followed by the interest in trying new products and recommendations made by family and friends in fourth and fifth positions. Habit of buying and impact of advertisement were the least ranked at sixth and seventh positions. The scores proved that advertisement has a very minimum impact over purchase decisions and the need of the product was the top most influential factor in inducing purchase intention of a consumer. 
Table 5

Garrett Ranking table for reasons of purchase

\begin{tabular}{|l|l|l|l|l|l|l|l|l|c|}
\hline Ranking & $\mathbf{1}$ & $\mathbf{2}$ & $\mathbf{3}$ & $\mathbf{4}$ & $\mathbf{5}$ & $\mathbf{6}$ & $\mathbf{7}$ & Total & Rank \\
\hline Garrett score & $\mathbf{7 9}$ & $\mathbf{6 6}$ & $\mathbf{5 8}$ & $\mathbf{5 0}$ & $\mathbf{4 3}$ & $\mathbf{3 5}$ & $\mathbf{2 2}$ & & \\
\hline Instruments & & & & & & & & & \\
\hline Necessity & 8769 & 4290 & 4176 & 5400 & 1419 & 35 & 66 & 61.4631 & $\mathbf{1}$ \\
\hline Advertisement & 2370 & 3366 & 2668 & 7150 & 2838 & 1085 & 572 & 51.01527 & $\mathbf{7}$ \\
\hline Cost of the product & 3239 & 5214 & 4930 & 5850 & 2365 & 420 & 88 & 56.24936 & $\mathbf{2}$ \\
\hline Brand reputation & 3318 & 4224 & 4756 & 6600 & 2193 & 455 & 198 & 55.32824 & $\mathbf{3}$ \\
\hline Recommended by friends \& family & 3160 & 2904 & 4466 & 6500 & 3182 & 455 & 110 & 52.86768 & $\mathbf{5}$ \\
\hline Habit & 2923 & 2640 & 4408 & 6300 & 2408 & 1470 & 352 & 52.16539 & $\mathbf{6}$ \\
\hline Trying new products & 2844 & 3564 & 3712 & 5600 & 3311 & 735 & 1056 & 52.98219 & $\mathbf{4}$ \\
\hline
\end{tabular}

\section{RESULTS AND DISCUSSION}

A consumer with more knowledge is believed to have more information about specific products or services. Earlier studies which focused on consumer's purchasing behaviour were also treating knowledge as a major factor determining their evaluation about a product [22]. Knowledge determines a consumer's sustainable purchasing behaviour and concern towards the environment [23] [24] In contradiction to the studies made earlier, the results of our study show that knowledge has a very minimal impact in influencing the purchase intention among consumers. Though people showed a positive attitude in gaining knowledge and information about green products, they did not have the actual purchase intention. Perception is not an instant reaction to the changes or reactions towards the external environment rather they are developed over a period of time. Attitude of an individual has a close relationship towards their perception [25].The results of our study conclude that green product perception holds strong relationship in influencing purchase intention. Among the various external factors that may influence the purchase decision of a consumer, perception plays a significant role. Though there may be so many reasons in purchasing a product, need and necessity of the product plays the primary role.

\section{LIMITATIONS AND FUTURE RESEARCH}

The study is limited to particular geographic location restricted to particular number of respondents. The available sources of information for the respondents play a major role in determining their knowledge. The resources and facilities were confined to a particular time frame of research.

The study can be performed with various set of respondents from different backgrounds. A larger set of respondents may be giving a broader view of results. The study can be conducted with very specific consumers related to niche products to obtain a very specific and clear view.

\section{REFERENCES}

1. Cohen, M. R. (1973). Environmental information versus environmental attitudes. The Journal of Environmental Education, $5(2), 5-8$.

2. Hendee, J. C. (1972). No, to attitudes to evaluate environmental education. Journal of Environmental Education, 3(3), 65-1972.

3. UNESCO (1977), "The international workshop on environmental education-finalreport",

:http://unesdoc.unesco.org/images/0002/000276/027608eb.

4. Keller, G.M., 1987. Industry and the environment: toward a new philosophy. Vital Speeches, 54(5), pp.154-157.

5. Kotler, Philip and Gerald Zaltman (1971). Social Marketing: An Approach to Planned Social Change, Journal of Marketing, Vol. No.35, (July), pp 3 - 12.

6. Ken Peattie, Linda Peters, (1997) "The marketing mix in the third age of computing", Marketing Intelligence \& Planning, Vol. 15 Iss: 3 , pp. $142-150$

7. Bohlen, G.M., Diamantopoulos, A. and Schlegelmilch, B.B., 1993 Consumer perceptions of the environmental impact of an industrial service. Marketing Intelligence \& Planning, 11(1), pp.37-48.

8. Elkington, J. 1994. Toward the Sustainable Corpor-ation: Win-Win-Win Business Strategies for Sustain-able Development,California Management Review,36(2): 90,100.

9. Polonsky, Michael Jay. 1994a. "Green Marketing Regulation in the US and Australia: The Australian Checklist." Greener Management International 5: 44-53.

10. Azzone, Giovanni and Raffaella Manzini. 1994. "Measuring Strategic Environmental Performance." Business Strategy and the Environment 3 (1): 1-14

11. Menon, A. and Menon, A., 1997. Enviropreneurial marketing strategy: the emergence of corporate environmentalism as market strategy. The Journal of Marketing, pp.51-67.

12. Schlegelmilch, B.B., Bohlen, G.M. and Diamantopoulos, A., 1996. The link between green purchasing decisions and measures of environmental consciousness. European journal of marketing, 30(5), pp.35-55.

13. Peattie, K., 1999. Trappings versus substance in the greening of marketing planning. Journal of Strategic Marketing, 7(2), pp.131-148.

14. Laroche, M., Tomiuk, M.A., Bergeron, J. and Barbaro-Forleo, G., 2002. Cultural differences in environmental knowledge, attitudes, and behaviours of Canadian consumers. Canadian Journal of Administrative Sciences/Revue Canadienne des Sciences de l'Administration, 19(3), pp.267-282. 
15. D'Souza, C., Taghian, M. and Lamb, P., 2006. An empirical study on the influence of environmental labels on consumers. Corporate communications: an international journal, 11(2), pp.162-173

16. Fischer, G., Shah, M., Tubiello, F.N. and Van Velhuizen, H., 2005. Socio-economic and climate change impacts on agriculture: an integrated assessment, 1990-2080.

17. Loureiro, M.L. and Lotade, J., 2005. Do fair trade and eco-labels in coffee wake up the consumer conscience? Ecological economics, 53(1), pp.129-138.

18. Sudhir Sachdev (2011) "Eco-friendly products and consumer perception". International Journal of Multidisciplinary Research. Vol 1. Iss 5.

19. Daugbjerg, C., Smed, S., Andersen, L.M. and Schvartzman, Y., 2014. Improving eco-labelling as an environmental policy instrument: knowledge, trust and organic consumption. Journal of Environmental Policy \& Planning, 16(4), pp.559-575.

20. Meyer, C., Kreft, H., Guralnick, R. and Jetz, W., 2015. Global priorities for an effective information basis of biodiversity distributions. Nature Communications, 6 .

21. Gutierrez, A.M.J.A. and Seva, R.R., 2016. Affective Responses in the Purchase of Consumer Eco Products. DLSU Business \& Economics Review, 25(2).

22. Alba, J. W., \& Hutchinson, J. W. (1987). Dimensions of consumer expertise. Journal of consumer research, 13(4), 411-454.

23. Vining, J., \& Ebreo, A. (1990). What makes a recycler? A comparison of recyclers and nonrecyclers. Environment and behavior, 22(1), 55-73.

24. Chan, R. Y. (2001). Determinants of Chinese consumers' green purchase behavior. Psychology \& marketing, 18(4), 389-413

25. Katona, G., \& Strümpel, B. (1978). A new economic era. North Holland.

\section{AUTHORS PROFILE}

K.Karmugilan, Full time research scholar in marketing management, Department of Management Studies, Pondicherry University. 3 years of working experience.MBA in HR and marketing specializations.

Dr.B. Rajeswari, Assistant Professor, Marketing and Operations, Department of Management Studies, Pondicherry University. More than 10 years of teaching experience. Placement co coordinator, research guide and organizer of conferences and workshops. 